IJ§ER

ISSN: 2149-5939
International Journal of Social Sciences and Education Research

Online, https://dergipark.org.tr/tr/pub/ijsser

Volume: 7(3), 2021

\title{
A study on self-assessment of current language skills: The case of Turkish teach- ers of English
}

\author{
Oya Tunaboylu ${ }^{1}$ and Tuğçe Çalışkan ${ }^{2}$ \\ *Corresponding author \\ ${ }^{1}$ Assoc. Prof., Dept. of English Language Teaching, Süleyman Demirel Uni., Isparta Turkey, ORCID: https://orcid.org/0000-0002-9926-7973 \\ ${ }^{2}$ Süleyman Demirel University, Isparta Turkey, tugcecirpancaliskan@gmail.com ORCID: https://orcid.org/0000-0002-1328-6672
}

\begin{tabular}{|c|c|}
\hline Article Info & Abstract \\
\hline Research Article & $\begin{array}{l}\text { As a consequence of increasing demand for learning a foreign language, the population of } \\
\text { language teachers has increased. As English is the most preferred language all over the }\end{array}$ \\
\hline Received:3 December 2020 & world, English language teachers have become a subject for examination. Given the fact the \\
\hline Revised: 20 March 2021 & majority of the English language teachers around the world are nonnative speakers their \\
\hline Accepted: 23 May 2021 & $\begin{array}{l}\text { proficiency has become crucial. This study aimed at providing baseline data on self-assess- } \\
\text { ment of Turkish teachers of English regarding their current proficiency in four language }\end{array}$ \\
\hline Keywords: & skills. Data for the study were collected through a three-part questionnaire based on CEFR \\
\hline English language teachers, & C1 can-do statements. A total of 70 Turkish teachers of English working in state and private \\
\hline Turkish teachers of English, & schools participated in the study. The findings revealed that teachers find themselves profi- \\
\hline Teacher competency, & cient in almost four language skills. The data collected also showed that Turkish teachers of \\
\hline Proficiency, & English mostly think that they are competent enough in conveying the meaning of what they \\
\hline CEFR & $\begin{array}{l}\text { read and they are more likely to use advanced vocabulary in written contexts than in spoken } \\
\text { interactions. However, the analysis of the open-ended questions revealed that there is still } \\
\text { room for language improvement. }\end{array}$ \\
\hline
\end{tabular}

\section{Introduction}

Today, as has been documented in many papers, English is the most common language around the world. Crystal (2017) suggests that a language can probably be a global language because not only it is spoken by a majority of people but also the country where the language belongs to has the power in almost every field such as economy, culture, technology and politics. Likewise, as Karakaş (2012) remarks, "the starring role of English in the current globalized world has augmented due to its being an international and well-recognized language across the world" (p.1). The global use of English among a diversity of nationalities, whose mother tongues are various, shows that English is a lingua franca. According to Seidlhofer (2004), English as a lingua franca means that people whose mother tongue is not English use the language as a means of communication because they have no other option to maintain communication. As a result of the need for learning English, language learning process has been an important factor. In this process, not only learning a new language itself but also teaching plays a vital role. As stated by Richards (2017) English is a commanding language around the world, thus the need for proficient teachers of English is increasing. As a consequence of the use of English as a lingua franca for several aims such as trade and education, it has become a must to be proficient in English around the world. Today, the need for a qualified English language teacher is felt more than ever.

Andrews (2003) stated that to be a qualified language teacher, one must know how to teach the language as well as the use of the language. There is a consensus in the related literature that mastery of subject matter along with pedagogical skills, that is, how to teach, both are important elements that constitute a qualified teacher. In order to be fully skilled both at language use and language teaching, there are some desirable teacher competencies. According to Atmaca (2017), English language teachers must be qualified in terms of designing teaching

* This research has Ethics Committee Approval from Suleyman Demirel University with 02/02/2020 date and 102/1 number.

To cite this article: Tunaboylu, O. \& Çalışkan, T. (2021). A study on self-assessment of current language skills: The case of Turkish teachers of English. International Journal of Social Sciences and Education Research, 7 (3), 194-203. DOI: https://doi.org/10.24289/ijsser.835494

Copyright (C) 2021 by IJSSER

ISSN: 2149-5939 
procedures, improving language skills, monitoring and assessing students' progress of the language learning, building bridges between families, society and institutions and improving their methodological knowledge in language teaching. To our surprise, there is an obvious dearth on the studies conducted on practicing English language teachers' proficiency in Turkey. Thus, this study is assumed to fill the gap thereby providing baseline data. The paper at hands aimed at finding out the proficiency level of Turkish teachers of English through self-assessment statements drawn from CEFR C1 level.

\section{Literature review}

Today, we live in a globalized and multicultural world which requires one to be competent in more than one language. Being the lingua franca for many around the world, English is one of the most-studied languages. With the increasing demand for learning English, the need for competent and proficient language teachers has come forth. Merriam-Webster defines competency as possession of sufficient knowledge or skill. Proficiency is the certainty of obtaining the skill for doing something. As argued by Hayes, Chang and Jeon (2017), language teachers all around the world are expected to adapt themselves to social changes and conduct their lessons considering cultural or global changes. This demand has made knowledge and skills are the main aspects which make a language teacher qualified enough to teach. In the related literature on teacher competencies, a variety of expectations have been listed (Mc Namara, 1991; Tsui 2003; Evans \& Lawes, 2007; Hayes et al 2017; Richards 2017). Underlying the significance of competent teachers, McNamara, for instance (1991), stated that students can learn a second language effectively only when language teachers mirror their extensive subject knowledge. Researchers highlight the importance of subject matter knowledge in a way that it seems inevitable for them to be a qualified teacher as "teachers who have greater subject knowledge are able to present concepts in a range of ways, help learners make connections between concepts and give learners practice in meaningful dialogues" (Tsui, 2003, p.54). In addition to McNamara and Tsui, Pachler and Evans Lawes (2007) claimed that a good language teacher must be knowledgeable in content.

In a recent paper by Richards (2017), language teachers' overall proficiency of the language has been stated as a must thereby securing the quality of education offered to students. Similarly, McNamara (1991) has stated his concerns about teachers' low proficiency levels and possible impacts of this insufficiency upon students. Many attempts to measure and enhance the language learning processes have been made in recent years. Council of Europe has developed the mostly-cited references of framework to evaluate language skills in Europe. Martyniuk (2005) remarks that language education activities carried out in accordance with the Council of Europe education policies emphasize the importance of plurilingualism, linguistic diversity, mutual understanding, democratic citizenship and social cohesion. Mirici (2007) states that the Language Policy Division of the Council of Europe developed The European Language Portfolio (ELP) to promote plurilingualism in language learning process. Common European Framework of Reference for Languages (CEFR) is considered as one of the most prominent actions of ELP. Council of Europe (2001) asserts that CEFR provides users with a common groundwork for curriculum, syllabus guidelines, materials and tests in Europe. Through a standard foundation, it becomes easier for learners, teachers, administers and institutions to pursue the language education programs and processes.

To measure and enhance second language competency is important in language learning process not only for plurilingual people but also for language teachers. In order to have the capacity to teach, one must be open to learn or be modest enough to accept whether he/she has points which need to be improved. Teaching and learning can be regarded as continuing processes which require lifelong effort. Not only students' but also teachers' need to keep up with the newest processes continue for life. As language is a dynamic process, teachers should prioritize keeping up to date themselves.

In order for teachers to keep up-to date, it is inevitable for teachers to be able to detect in which areas they are competent enough or in what fields that need improvement. Selvi (2007) argues that teachers' lifelong learning skills involve being aware of their own capacities as teachers and individuals and identifying their own educational needs. As mentioned earlier, in order to carry on daily tasks such as giving instructions, provide explanations, simply communicate in the target language, but most of all in order to address to the needs of the students in the 21 st century, teachers are expected to be proficient in not only the language skills but also these skills such as critical thinking, problem solving and creativity as well.

In Turkey, in order to work as a professional teacher of English, one has to be the graduate of primarily fouryear English Language Teaching departments (ELT) or related programs. At present, there are around sixty universities providing offering ELT programs in Turkey. Following graduation from these programs with a Bachelor's degree and receiving a pre-determined score from KPSS exam, the acronym stands for 'public employee Copyright (C) 2021 by IJSSER

ISSN: 2149-5939 
selection exam' the graduates are allowed to work for public schools. Along with the ELT departments, English language teachers, in Turkey, might also be the graduates of other departments such as English Language and Literature, English Translation, American Culture and Literature and Linguistics. With regard to this issue, İnceçay (2011) and Karakaş (2012) remark that the programs in the field of ELT do not provide their students with pedagogical knowledge. However, upon successful completion of a two-semester long certificate program offered by the Schools of Education on pedagogical knowledge and having a passing score from the abovementioned national KPSS exam the graduates can also work as English language teachers in Turkey. Typically, ELT departments offer prospective English language teachers eight semesters in four years with or without one year long English preparatory education. The courses offered in the ELT departments fall under three categories; languageproficiency courses, linguistics-related courses and pedagogical courses. The curriculum followed in these programs is more or less similar across the country. That is, the curriculum is of centralized nature.

As mentioned earlier, language teachers are expected to give instructions, provide explanations and communicate in the target language, which is English in our case. Therefore, their proficiency is of utmost importance.

With this in mind, the current study aimed at finding answers for the following research questions;

1. What is the self-assessed proficiency level of the participants, who are Turkish English teachers of English working for public and private schools, in terms of listening?

2. What is the self-assessed proficiency level of the participants in terms of speaking?

3. What is the self-assessed proficiency level of the participants in terms of reading?

4. What is the self-assessed proficiency level of the participants in terms of writing?

5. Are there any differences in the self-assessed proficiency levels of teachers with regard to gender, type of school currently worked, and teaching experience?

\section{Methodology}

Quantitative research design was adopted to address the research questions stated above. The data were collected through an online survey. The survey was started on 18th April, 2020 and closed on 5th May, 2020. The study was conducted to find out English language teachers' self-assessed proficiency in English based on CEFR $\mathrm{C} 1$ level specifications. In the following sections, data collection tool, data collection and data analysis will be mentioned.

\subsection{Participants}

A total of 70 participants participated in this study. Of them 19 were male and 51 of them were females. 22 participants have $0-5$ year of experience, 19 of total participants have 6-10 year of experience and 29 of them are $10+$ year experienced teachers. While 37 of the teachers work in private schools, 33 of the participants work in state schools.

\subsection{Data collection}

This research has been conducted by using quantitative research method. Quantitative method provides researchers with more reliable outcomes as numbers which symbolize results expand the objectivity of the study without including personal interpretation (Dörnyei, 2007). In other words, quantitative research method indicates impersonal and statistical analysis of data which is gathered through polls, questionnaires and surveys or by reshaping numeric results which were uncovered by previous studies. Quantitative method is a reliable way to access data as well as it is practical for researchers. Because this method does not require transcription of participants' answers, it is also timesaving.

In this study, a questionnaire was used to collect data. The questionnaire was designed by the researchers within the framework of CEFR and included 3 parts. The items of the questionnaire were adapted from the cando statements of the CEFR C1 level. The earlier version of the questionnaire was piloted with 20 teachers who are not included in the current study. Based on the pilot study of the questionnaire some modifications were made in wording. Included in the questionnaire Part A consisted of 3 personal questions. Dörnyei (2007) interprets personal questions, in other words factual questions, as the ones which require personal facts such as age, gender and work experience. In this research, personal questions involved gender, teaching duration and the institution type as to whether state or private school. Including 34 items in total, Part B can-do statements were arranged at 5-point Likert scale ranging from 'strongly agree, agree, neutral, disagree and strongly disagree'. As for the items, from the items number 4 to 11 were related to the receptive skills, which are reading and listening, while the ones from 
12 to 37 were based on productive skills; speaking and writing. The last part of the questionnaire Part C consisted of 2 open-ended questions related to the assumed weaknesses of the teachers in terms of language skills and the improvement endeavors they are involved in. In order to collect data for the study convenience sampling procedure was adopted. The questionnaire was delivered to the participants in two ways. First, a master copy of the questionnaire was mailed to the principals and kindly requested to share it with the English language teachers who work in their schools and would volunteer to participate in the study. Second, the participants from researchers' network were provided with the soft copy version of the survey adapted from CEFR via Google Docs (see the Appendix for the questionnaire).

\subsection{Data analysis}

39 items; 3 from Part A, 34 from Part B and 2 from Part C in the questionnaire, were loaded into the program. The first part of the questionnaire included 3 questions to elicit biographical information as "gender, teaching experience and the type of school currently working". For gender variable; $1=$ Male, $2=$ Female, for teaching experience; $1=0-5$ years, $2=6-10$ years, and $3=10+$ years, for school type; $1=$ State, $2=$ Private, accordingly, each option was assigned a number. In Part B, statements from 4 to 11 were related to receptive skills, which are reading and listening, while the statements from 12 to 37 were based on productive skills, which are speaking and writing at Likert scale through 'strongly agree, agree, neutral, disagree and strongly'. They were assigned numbers 1,2 , 3, 4 and 5 respectively. Cronbach Alpha for the instrument was measured as .087 . Internal consistency of the rephrased questions after the pilot study was measured to ensure the internal consistency. To analyze the data IBM SPPS version 22 was used. Part C consisted of 2 open-ended questions (Q.38, Q.39). The analysis of the openended questions was made through content analysis. The responses to the Question 38 that the assumed weaknesses in terms of English language skills yielded 6 sub-categories as listening, speaking, reading, writing, and vocabulary. Question 39 that asked the participants their endeavors to improve their assumed weaknesses was categorized into two variables; $1=$ Individual, $2=$ Institutional.

Results were presented through figures and tables below.

\section{Results}

This part will display the findings obtained out of the statistical measurement for each research question. Table 1 shows that means of listening skill related items are closer to 2 (agree), which reveals that participants perceive themselves as proficient in English language listening skills. As can be seen in Table 2, the participants' responses to the items with regard to their speaking proficiency are close to 2 (agree), which shows that, like in the listening skill, participants are of the opinion that they are also competent at speaking skills.

Research question 1: What is the self-assessed proficiency level of the participants in terms of listening?

Table 1. Self-assessed proficiency level of the participants in terms of listening

\begin{tabular}{llc}
\hline & Mean \\
\hline Q4 & 1,7143 \\
Q5 & 1,7143 \\
Q6 & 1,9286 \\
\hline
\end{tabular}

Research question 2: What is the self-assessed proficiency level of the participants in terms of speaking?

Table 2. Self-assessed proficiency level of the participants in terms of speaking

\begin{tabular}{ll}
\hline & Mean \\
\hline Q12 & 1,8286 \\
Q13 & 1,8857 \\
Q15 & 1,7857 \\
Q17 & 1,7714 \\
Q18 & 1,9857 \\
Q19 & 1,9143 \\
Q24 & 1,9429 \\
Q25 & 2,0429 \\
Q26 & 1,7714 \\
Q27 & 1,7714 \\
Q34 & 1,8429 \\
\hline
\end{tabular}


Research question 3: What is the self-assessed proficiency level of the participants in terms of reading?

Table 3. Self-assessed proficiency level of the participants in terms of reading

\begin{tabular}{lll}
\hline & Mean \\
\hline Q7 & 1,9143 \\
Q8 & 1,7571 \\
Q9 & 2,0571 \\
Q10 & 2,0286 \\
Q11 & 2,2143 \\
\hline
\end{tabular}

Table 3 indicates the means of reading skill related items are closer to 2 (agree). A scan be deduced from the mean scores of reading skills teachers consider themselves as highly competent also in reading-based skills. Table 4 reveals that teachers' perspective on their own writing skills is highly positive. Means of writing related items are closer to 2 (agree).

Research question 4: What is the self-assessed proficiency level of the participants in terms of writing?

Table 4. Self-assessed proficiency level of the participants in terms of writing

\begin{tabular}{lc}
\hline & Mean \\
\hline Q20 & 1,7000 \\
Q21 & 1,7857 \\
Q22 & 1,7857 \\
Q23 & 1,8143 \\
Q28 & 1,6143 \\
Q29 & 1,6714 \\
Q31 & 2,0000 \\
Q32 & 1,9714 \\
\hline
\end{tabular}

Research question 5: Are there any differences in the self-assessed proficiency levels of teachers with regard to gender, type of school currently working, and teaching experience?

Table 5. Tests of normality

\begin{tabular}{lcccccc}
\hline & \multicolumn{3}{c}{ Kolmogorov-Smirnov } & \multicolumn{3}{c}{ Shapiro-Wilk } \\
\cline { 2 - 7 } & Statistic & $\mathrm{df}$ & $\mathrm{p}$. & Statistic & $\mathrm{df}$ & $\mathrm{p}$. \\
teaching experience &, 268 & 70 &, 000 &, 771 & 70 &, 000 \\
school type &, 354 & 70 &, 000 &, 635 & 70 &, 000 \\
gender &, 456 & 70 &, 000 &, 556 & 70 &, 000 \\
\hline
\end{tabular}

Statistically speaking, when there are more than 30 participants in a study Kolmogorov-Smirnov test is advised. If the test reveals a $\mathrm{p}$ value greater than 0,05 , it means distribution is normal. According to Table 5, KolmogorovSmirnov test does not indicate a normal distribution. Therefore, non-parametric tests are required to compare teaching experience, school type and gender. When independent groups are compared, Independent Samples t Test is used for the assessment of differences of related groups. This test would be appropriate for the comparison of teaching experience, school type and gender. However, as Kolmogorov-Smirnov test lacks normal distribution, it necessitates the use of a non-parametric test like Mann Whitney U. Gender, the type of school and teaching experience might affect participants' self-assessment of language skills. Thus, following hypotheses were constituted with regards to the research question 5 .

H0: Gender, school type and teaching experience do not make any difference in the self-assessment of English language proficiency of the participating teachers.

H1: Gender, school type and teaching experience make a significant difference in the self-assessment of English language proficiency of the participating teachers.

The Mann Whitney $U$ test requires the check of $p$ value during the interpretation process. The null hypothesis is to be retained if $\mathrm{p}$ value is higher than .05 . The null hypothesis is to be rejected when $\mathrm{p}$ value is lower than .05 . Taking this into consideration, Table 6 reveals that items 7, 8,21, 22, 28, 30 and 33 indicate a significant difference between gender and self-assessed proficiency of teachers. This difference occurs in the items related to written texts, written interaction, grammar and expressing point of view. 
Table 6. Mann Whitney U test results on comparison of survey items with gender

\begin{tabular}{|l|c|}
\hline \multicolumn{1}{|c|}{ Items } & Significance \\
\hline 7. Long and complex factual texts are easy for me to understand & .056 \\
\hline 8. I can differentiate the styles of texts such as factual and literary texts & .918 \\
\hline 21. I am good at precise expression during written interaction & .685 \\
\hline 22. I can relate to the addressee in an assured style during written interaction & .411 \\
\hline 28. I can express myself in a clear written text & .855 \\
\hline 30. I can express points of view at some length & .209 \\
\hline 33. I can consistently maintain a high degree of grammatical accuracy & .035 \\
\hline
\end{tabular}

Type of the school in which participants work is another point that concerns the hypotheses for the research question 5. Table 7 compares the survey items to the school type. It shows that items 7, 14 21, 22, 27, 29 and 32 reveal a significant difference between school type and self-assessed proficiency of the participants. These items are mostly related to writing, which means writing causes the difference in question.

Table 7. Mann Whitney U test results on comparison of survey items with school type

\begin{tabular}{|l|c|}
\hline \multicolumn{1}{|c|}{ Items } & Significance \\
\hline 7. Long and complex factual texts are easy for me to understand & .252 \\
\hline 14. I can use language flexibly for professional purposes & .361 \\
\hline 21. I am good at precise expression during written interaction & .451 \\
\hline 22. I can relate to the addressee in an assured style during written interaction & .208 \\
\hline 27. I can develop points while speaking. & .207 \\
\hline 29. I can express myself in a well-structured text while writing. & .137 \\
\hline $\begin{array}{l}\text { 32. Determining the appropriate style to the reader in mind while writing different kinds of texts is easy } \\
\text { for me }\end{array}$ & .000 \\
\hline
\end{tabular}

Hypotheses for the research question 5 include teaching experience of the participants, as well. All the survey items retain the null hypothesis, which means teaching experience of teachers does not make any impact on their self-assessed proficiency levels.

Part $\mathrm{C}$, which requires open-ended answers from participants, reveals that many teachers are aware of the skills they need to further develop to be able pursue their occupations. 9 participants mentioned they could be better at listening while 25 participants were of the opinion that it was necessary for them to enhance speaking skills. 12 participants thought they needed better writing skills while 12 teachers felt they needed more vocabulary knowledge. 8 teachers stated that they needed better reading skills for their career while 4 participants claimed they did not have any area to improve. What needs to be noted here in the open-ended findings do not resonate with the findings extracted from the questionnaire. Although the Likert scale questionnaire items show that the participating Turkish teachers of English are of the opinion that they are competent enough in almost four language skills in English, open-ended items reveal that teachers think they have a room for development. It might result from the fact that open-ended items enable teachers to think more globally while Likert scale items focus on more specific areas. The last question item 39 asked the participants what types of endeavors they are involved in to improve their language skills. The content analysis revealed that 52 teachers are involved in individual activities such as following professional web sites on social media, professional readings, browsing and downloading language applications to enhance their skills while 18 teachers participate in institutional activities such as seminars, conferences, school projects.

\section{Discussion and conclusion}

The current study investigated the self-assessed proficiency of Turkish teachers of English working at state and private schools in Antalya. A total of 70 teachers participated in the study. In order to collect data a questionnaire designed by the researchers was used. The items were drawn from the can-do statements in the CEFR C1 specifications. The data collected were analyzed by IBM SPSS program version 22 . The findings were presented in Tables and figures.

Niculescu (2014) states that English language teachers need a number of competencies to be able to perform their occupation. Richards (2001) defines competency as a trait of a person which helps him/her to perform a task, function or activity in a professional environment. Skills such as reading, writing, speaking and listening are accounted as content knowledge in English language teaching. Content knowledge is among the competencies that a teacher needs to be able to perform teaching efficiently. Shulman and Shulman (2004) define an accomplished 
teacher as a person who knows what to teach and how to teach. Therefore, it is important for an English language teacher to be proficient in reading, writing, speaking and listening skills and to be sufficient in teaching those skills. Williams (1975) claims that a competent language teacher needs to have good knowledge of target language and good teaching skills. A study by Mukmimin, Sulistiyo, \& Yanto (2016) reveals that improving language skills among new teachers is highly important. Although their study differs from our study in terms of the participants' profile, that their participants are teacher educators and school principals it aligns with our study in terms of the importance of teachers' language skills.

As mentioned earlier in the paper, proficiency of English language teachers is an under researched area. In a similar study Alvarenga et al (2009) investigated language teachers' proficiency by using a computerized test. Their study and the present study both investigated the proficiency of the English language teachers, the data collection methods are different. The findings of the present study revealed inconsistency. Although almost all of the participating teachers stated that they are proficient in the four-language skills area, in the open-ended part of the questionnaire almost all of them expressed the area they need to improve. As well as being currently involved in some events and actions for their own development, they are willing to participate in some other events and actions for further development. A study by Hizriani and Rahayu (2014) shows that teachers reflect on their own personal traits and collaborate with other teachers to improve themselves professionally.

Another study conducted by Kömür (2010) looked at the self-efficacy of Turkish teachers of English. The study revealed that the participating teachers are aware of their level in terms of their teaching skills. However, the study did not focus on language proficiency of teachers. The current study intended to provide some data about the self-assessment of English language teachers regarding their own English language skills competency. The more competent teachers think they are, the more motivated they are to do their jobs efficiently. Deci and Ryan (2002) mention that motivation emerges from innate psychological needs such as self-efficacy feeling. In addition, Bandura (1977) claims that teachers' performance and success in their professions result from their own beliefs about their abilities. Seeing this, the study might contribute to professional life of teachers by raising awareness about their competency.

Elder (2001) points out the unavoidable connection between language skills and pedagogical performance of language teachers. The researchers argue that CEFR can be taken as a reference to measure the language proficiency of teachers. Our study aimed at providing some implications and baseline data for further studies which can examine proficiency of teachers based on CEFR. It can also promote personal and institutional teacher development actions. Richard (2001) remarks that conferences, seminars and similar activities are necessary for teachers to update their skills. Focusing on the language skills beside professional development might contribute to teachers' professional life to a great extent. This study might foster the organization of such activities for teachers. Büyükyavuz and İnal (2008) state that teachers should be taught the difference between 'teacher training' and 'teacher development' when teacher candidates are receiving training. Then ongoing professional development might come to a prominence among English language teachers.

\section{Limitations}

This study was conducted on a small number of participants accordingly with limited data. That is, the findings cannot be generalized beyond this sample. In addition to the small sample, computerized research did not yield any previous study conducted specifically on language proficiency of Turkish teachers of English. Therefore, secondary data presented in the literature review lack studies in this respect. Another point to mention with regard to limitations, questionnaire was the only data collection tool utilized in the study. In a further large-scale study, interviews and classroom observations might be included. This type of triangulation will enhance the trustworthiness of the collected data.

\section{Recommendations for further study}

Based on the findings of the current study, we can say that although questionnaire teachers are well aware of low proficiency language-related weaknesses and willing to get involved in activities to improve these areas. Another research might investigate the opportunities available to teachers in Turkey. However, this research needs to be replicated with a larger sample to gain data in larger areas and boarder contexts. In order to capture the proficiency picture of Turkish teachers of English working in Turkey, this study can be replicated with a larger sample. In order to triangulate the data, focus group interviews can be integrated into the study. Apart from the studies on language proficiency, studies on how to measure the effectiveness and how to improve the training and development programs can be conducted. 


\section{Author contribution statements}

O. Tunaboylu and T. Çalışkan contributed equally to the design and implementation of the research, to the analysis of the results and to the writing of the manuscript.

\section{Disclosure statement}

No potential conflict of interest was reported by the authors.

\section{Ethics committee approval}

This research has Ethics Committee Approval from Suleyman Demirel University with 02/02/2020 date and 102/1 number. All responsibility belongs to the researchers. All parties were involved in the research of their own free will.

\section{References}

Alvarenga, M. B., Concario, M., Consolo, D. A., Lanzoni, H., Martins, T. H. B., \& Silva, V. (2009). An examination of foreign language proficiency for teachers (EPPLE): The initial proposal and implications for the Brazilian context. In Congresso Internacional Da Abrapui, 2, 1-15.

Andrews S (2003) Teacher language awareness and the professional knowledge base of the L2 teacher. Language Awareness 12(2): 81-95.

Atmaca, Ç. (2017). English teachers' perspectives about teacher competencies in terms of professional identity. Abant İzzet Baysal Üniversitesi Eğitim Fakültesi Dergisi, 17 (4), 1641-1669.

Bandura, A. (1977). Self-efficacy: Toward a unifying theory of behavioral change. Psychological Review, 84, 191-215.

Büyükyavuz, O. \& İnal, S. (2008). A Descriptive Study on Turkish Teachers of English Regarding their Professional Needs, Efforts for Development and Available Resources. The Asian EFL Journal Quarterly, 10(3), 215-233.

Competency. (2020). In Merriam-Webster's online dictionary. Retrieved from https://www.merriam-webster.com/dictionary/competency

Council of Europe. (2001). Common European framework of reference for languages. Cambridge UP: Cambridge.

Crystal, D. (2017). English as a global language (Second edition.). Cambridge, UK; New York: Cambridge University Press.

Deci, E. L., \& Ryan, R. M. (2002). Handbook of self-determination research. (Eds.). Rochester, NY: Un. of Rochester Press.

Elder, C. (2001). Assessing the language proficiency of teachers: are there any border controls?. Language Testing,18(2), 149170

Hayes, David \& Chang, Kyungsuk \& Jeon, Young-Joo. (2017). Competency Frameworks and Implications for Teacher Assessment. Advanced Science Letters. 23. 9778-9782. 10.1166/asl.2017.9796.

Hizriani, N. \& Rahayu, P. S. (2014). English teachers' professional development at Hulu Sungai Selatan. South Kalimantan. Paper presented at the TEFLIN International Conference, Solo, Indonesia.

İnceçay, G. (2011). A critical overview of language teacher education in Turkish education system: From 2nd constitutional period onwards (1908-2010). Procedia - Social and Behavioral Sciences, 15, 186-190. https://doi.org/10.1016/j.sbspro.2011.03.071

Karakaş, A. (2012). Evaluation of the English language teacher education program in Turkey. ELT Weekly, 4(15). 1-16.

Kömür, Ş. (2010). Teaching knowledge and teacher competencies: a case study of Turkish preservice English teachers. Retrieved from: https://www.tandfonline.com/doi/full/10.1080/10476210.2010.498579?scroll=top\&needAccess=true

Martyniuk, M. (2005). Relating language examinations to the Council of Europe's Common European Framework of Reference for Languages (CEFR). Taylor, L.\& Weir C.J. (Eds.). Multilingualism and Assessment (pp. 9-20). Retrieved from https://www.tandfonline.com/doi/full/10.1080/15434303.2010.498905?casa_token=6gJTZ4BRemcAAAAA:FBCXPe8NjfD2bFdyEe6YmXHjrSZapngvHaFd0jqXkU5oSFuYzc_cCMcQHp4sgChBXNbkNsY17gZ_9LQ

McNamara, D. 1991. Subject knowledge and its application: problems and possibilities for teacher educators. The Journal of Education for Teaching, 17(2): 113-128.

Mirici, I. H. (2007). Training multicultural and plurilingual children with an identity of European citizenship. Proceedings of the International Academic Conference Children's Identity and Citizenship in Visegrad Context, Presov University, 2932.4. 
Mukmimin, A., Sulistiyo, U.\& Yanto, Y. (2016). In the Spirit of Quality Student Teachers' English Proficiency and Pedagogical Skills: Teacher Educators and School Principals' Perception. Turkish Journal of Education, 5(3). 157-169. Doi: $10.19128 /$ turje. 81461

Niculescu, B. O. (2014). Specific Competencies Required in Promoting the Quality of the English Language Teaching Process. Buletin Stiintific, 2(38), 144-151.

Pachler, N., Evans, M. and Lawes, S. 2007. Modern Foreign Languages: Teaching School Subjects 11-9, Oxford: Routledge.

Richards, J. C. (2001). Curriculum development in language teaching. Cambridge, UK: Cambridge University Press. Richards, J. C.

Richards, J. C. (2017). Teaching English through English: Proficiency, pedagogy and performance. RELC Journal, 48(1), 730.

Seidlhofer, Barbara. (2004). Research Perspectives on Teaching English as a Lingua Franca. Annual Review of Applied Linguistics. 24. 209 - 239. 10.1017/S0267190504000145.

Selvi, K. (2007, May 30-June 2). The English language teachers' competencies. Paper presented at The Fifth International JTET Conference, University of Debrecan, Hungary.

Shulman, L. S. \& Shulman, J. H. (2004). How and what teachers learn: A shifting perspective. Journal of Curriculum Studies, $36(2), 257-271$.

Williams, W. (1975). The training teachers of English as a foreign language. English Language Teaching Journal, 29, 107-115. 
Appendix

\section{Questionnaire}

Part A. Please answer the following personal questions.

Gender:

Teaching experience

School type (State or Private):

Part B. Please choose $(\checkmark$ or $\mathbf{X})$ the suitable ones from strongly agree to strongly disagree for the following items.

\begin{tabular}{|c|c|c|c|c|c|}
\hline & $\begin{array}{l}\text { Strongly } \\
\text { Agree }\end{array}$ & Agree & Neutral & Disagree & $\begin{array}{l}\text { Strongly } \\
\text { Disagree }\end{array}$ \\
\hline \multicolumn{6}{|l|}{ Extended speech is easy for me to understand. } \\
\hline \multicolumn{6}{|l|}{ I can understand television programmes and films with little effort. } \\
\hline \multicolumn{6}{|l|}{ I can understand implicit speech. } \\
\hline \multicolumn{6}{|l|}{ Long and complex factual texts are easy for me to understand. } \\
\hline \multicolumn{6}{|l|}{$\begin{array}{l}\text { I can differentiate the styles of texts such as factual and literary } \\
\text { texts. }\end{array}$} \\
\hline \multicolumn{6}{|l|}{ I can understand specialized articles. } \\
\hline \multicolumn{6}{|l|}{ I can understand long and complex literary texts. } \\
\hline \multicolumn{6}{|l|}{ Long technical instructions are asy for me to understand. } \\
\hline \multicolumn{6}{|l|}{ I am good at fluent oral expression. } \\
\hline \multicolumn{6}{|l|}{ I can use oral language flexibly for social purposes. } \\
\hline \multicolumn{6}{|l|}{ I can use language flexibly for professional purposes. } \\
\hline \multicolumn{6}{|l|}{ I can express myself non-stop. } \\
\hline \multicolumn{6}{|l|}{ I can use language effectively in professional contexts. } \\
\hline \multicolumn{6}{|l|}{ I can use oral language effectively in social contexts. } \\
\hline \multicolumn{6}{|l|}{ I can produce arguments with precision. } \\
\hline \multicolumn{6}{|l|}{$\begin{array}{l}\text { I am good at producing coherent responds to those of other speak- } \\
\text { ers during spoken interaction. }\end{array}$} \\
\hline \multicolumn{6}{|l|}{ I can express myself with clarity during written interaction. } \\
\hline \multicolumn{6}{|l|}{ I am good at precise expression during written interaction. } \\
\hline \multicolumn{6}{|l|}{$\begin{array}{l}\text { I can relate to the addressee in an assured style during written in- } \\
\text { teraction. }\end{array}$} \\
\hline \multicolumn{6}{|l|}{$\begin{array}{l}\text { I can relate to the addressee in a personal style during written in- } \\
\text { teraction. }\end{array}$} \\
\hline \multicolumn{6}{|l|}{$\begin{array}{l}\text { I can present clear descriptions of complex subjects while speak- } \\
\text { ing. }\end{array}$} \\
\hline \multicolumn{6}{|l|}{$\begin{array}{l}\text { I can present detailed descriptions of complex subjects while } \\
\text { speaking. }\end{array}$} \\
\hline \multicolumn{6}{|l|}{ I can integrate sub-themes while speaking. } \\
\hline \multicolumn{6}{|l|}{ I can develop points while speaking. } \\
\hline \multicolumn{6}{|l|}{ I can express myself in a clear written text. } \\
\hline \multicolumn{6}{|l|}{ I can express myself in a well-structured text while writing. } \\
\hline \multicolumn{6}{|l|}{ I can express points of view at some length. } \\
\hline \multicolumn{6}{|l|}{$\begin{array}{l}\text { Writing detailed expositions of complex subjects in an essay or a } \\
\text { report is easy for me. }\end{array}$} \\
\hline \multicolumn{6}{|l|}{$\begin{array}{l}\text { Determining the appropriate style to the reader in mind while writ- } \\
\text { ing different kinds of texts is easy for me. }\end{array}$} \\
\hline I can consistently maintain a high degree of grammatical accuracy. & & & & & \\
\hline $\begin{array}{l}\text { I can communicate with occasional minor slips, without signifi- } \\
\text { cant vocabulary errors. }\end{array}$ & & & & & \\
\hline I have a good command of expressions and colloquialism. & & & & & \\
\hline I have a good command of lexical repertoire. & & & & & \\
\hline I can use organizational patterns, connectors and cohesive devices. & & & & & \\
\hline
\end{tabular}

Part C. Please answer the following open-ended questions.

Which skill/s or area/s would you like to improve?

What types of activities are you involved to improve your proficiency? 